\title{
Comparison of normal saline solution with low-chloride solutions in renal transplants: a meta-analysis
}

\author{
Abdullah Jahangir ${ }^{1}$, Syeda Sahra ${ }^{1}$, Muhammad Rafay Khan Niazi ${ }^{1}$, Fasih Sami Siddiqui ${ }^{1}$, \\ Muhammad Yasir Anwar ${ }^{2}$, Ahmad Jahangir ${ }^{2}$, Elie J. El-Charabaty ${ }^{1}$ \\ ${ }^{1}$ Department of Internal Medicine, Staten Island University Hospital, Northwell Health, Staten Island, NY, United States \\ ${ }^{2}$ Department of Internal Medicine, King Edward Medical University, Lahore, Pakistan
}

Background: Normal saline solution (NSS) has been the fluid of choice for renal transplant patients, but it can lead to hyperchloremic acidosis and hyperkalemia. This study was performed to compare the safety profile of low-chloride solutions with that of NSS in renal transplant patients.

Methods: We conducted a systemic review search on PubMed, Embase, and the Central Cochrane Registry. Randomized clinical trials (RCTs) and matched cohort studies involving NSS as the control arm and low-chloride solutions as an intervention arm were chosen. The standardized mean difference for continuous variables, the odds ratio (OR) for discrete variables, and a $95 \%$ confidence interval $(\mathrm{Cl})$ for effect sizes were used. A p-value of $<0.05$ was considered statistically significant. Analysis was performed using a random-effects model irrespective of heterogeneity, which was evaluated using $I^{2}$ statistics.

Results: Nine RCTs and one cohort study with a total of 726 patients were included. After transplantation, serum potassium was significantly lower in the low-chloride group (standardized mean difference compared to NSS group, $-0.38 \mathrm{mEq} / \mathrm{L} ; 95 \% \mathrm{Cl},-0.66$ to -0.11; $p=0.007)$. Similarly, postoperative chloride was lower in the low-chloride group $(-2.41 \mathrm{mEq} / \mathrm{L}[-3.34$ to -1.48$], \mathrm{p}<0.001)$. No statistically significance was observed in delayed graft function (OR, 0.98 [0.56-1.69], $p=0.93)$, day $3 \mathrm{creatinine}(-0.14 \mathrm{mg} / \mathrm{dL}$ [-0.46 to 0.18], $p=0.38$ ), or day 7 urine output ( $-0.08 \mathrm{~L}$ [ -0.29 to 0.12$], p=0.43$ ).

Conclusion: Use of NSS during renal transplant leads to increased incidence of hyperchloremic acidosis with subsequent hyperkalemia, but clinical significance in the form of delayed graft function or postoperative creatinine remains comparable to that of low-chloride solutions.

Keywords: Delayed graft function, Dialysis solutions, Kidney transplantation, Ringer's lactate, Saline solution, Sodium bicarbonate

\section{Introduction}

End-stage renal disease is a significant cause of global morbidity and mortality, with kidney transplantation being the treatment of choice as it offers substantial survival benefits over dialysis.

The total number of kidney transplants is increasing steadily every year. According to the data obtained from Or-

Received: February 4, 2021; Revised: April 11, 2021; Accepted: April 25, 2021

Editor: Sejoong Kim, Seoul National University, Seongnam, Republic of Korea

Correspondence: Syeda Sahra

Department of Internal Medicine, Staten Island University Hospital, 475 Seaview Ave, Staten Island, NY 10305, USA. E-mail: ssahra@northwell.edu ORCID: https://orcid.org/0000-0003-0119-3329

Copyright (C) 2021 by The Korean Society of Nephrology

() This is an Open Access article distributed under the terms of the Creative Commons Attribution Non-Commercial and No Derivatives License (http:// creativecommons.org/licenses/by-nc-nd/4.0/) which permits unrestricted non-commercial use, distribution of the material without any modifications, and reproduction in any medium, provided the original works properly cited. 
gan Procurement and Transplantation Network government website, 22,393 patients received a renal transplant in 2018. According to the annual report 2020 published by the United States Renal Data System, 1-year posttransplant graft survival improved to $93 \%$ in deceased donor transplant recipients compared to $96.9 \%$ in living donor transplant recipients. The limited availability of donor viscera necessitates measures to improve graft function and survivability.

Normal saline solution (NSS) is the most used perioperative intravenous fluid during kidney transplant due to theoretically reduced risk for perioperative hyperkalemia [1]. It is postulated that fluids like Ringer's lactate possess a high potassium content and can cause hyperkalemia postoperatively [2,3]. There is some evidence that suggests that higher chloride content in NSS can cause hyperchloremic metabolic acidosis and subsequent hyperkalemia as an effect of acidosis on potassium homeostasis [4].

In comparison, balanced chloride solutions are less likely to cause hyperkalemia by virtue of their low-chloride content. This meta-analysis will determine if we can extrapolate these electrolyte and blood pH changes associated with NSS to renal transplant surgeries. Hyperkalemia is an indication for dialysis posttransplant and can lead to decreased cardiovascular stability of the transplant recipient. Therefore, it is hypothesized that normal saline will increase the risk of delayed graft function, defined as the need for dialysis within 1 week of renal transplantation or not observing a $20 \%$ reduction in serum creatinine within 72 hours [5].

The purpose of this review is to compare NSS to balanced crystalloid solutions and the incidence of postoperative delayed graft function, acidemia, and hyperkalemia in renal transplant patients. With the last being in 2016, previous reviews support that NSS is associated with more hyperchloremic metabolic acidosis than are balanced electrolyte solutions, but with uncertain clinical significance [6]. However, three randomized clinical trials (RCTs) on the topic have been performed since 2016, requiring their inclusion for a higher-powered review. We aim to increase the study power by including recently published trials and provide a more comprehensive guideline for physicians overseeing the care of renal transplant patients.

\section{Methods}

The databases accessed were the Cochrane Central Registry of Clinical Trials, Embase, and PubMed. The search terms used were renal transplant, sodium bicarbonate, normal saline solution, and Ringer's lactate. The deadline for publication was set as December 20, 2020. The data were extracted, and the manuscript was reviewed by the Research Department and Ethics Committee. No experimental interventions were performed, and it did not require any specification of guidelines, legislations, or permissions.

\section{Inclusion and exclusion criteria}

Included papers had the following characteristics.

(1) Randomized control trials or matched retrospective cohort studies comparing NSS against low-chloride solutions in renal transplant patients

(2) Patients older than 18 years

(3) Available in English without restrictions of date or status of publication

Papers that did not meet the above criteria were excluded.

\section{Trial selection and evaluation}

Three authors independently reviewed all articles and abstracts and excluded irrelevant articles. The risk of bias for selected papers was assessed using the Cochrane collaborative tool and was classified into high, uncertain, and low.

\section{Data extraction}

Information was extracted using a prespecified extraction table from analysis of text and tables, and a second author reviewed the information to ensure accuracy. The extracted data were the number of patients, delayed graft function, serum creatinine at day $3(\mathrm{mg} / \mathrm{dL})$, urine output at day $7(\mathrm{~L})$, postoperative chloride $(\mathrm{mEq} / \mathrm{L})$, postoperative potassium (mEq/L), postoperative blood $\mathrm{pH}$, postoperative base excess $(\mathrm{mEq} / \mathrm{L})$, and postoperative bicarbonate $(\mathrm{mEq} / \mathrm{L})$.

\section{Statistical analysis}

The meta-analysis was performed using the Comprehensive Meta-Analysis software version 3 (Biostat Inc., Englewood, NJ, USA). We calculated the standardized mean difference in continuous variables for treatment effect measurements, 
while the odds ratio (OR) was calculated for discrete variables. Standard errors were calculated using a 95\% confidence interval (CI), and a p-value of 0.05 was used for determining statistical significance. For consistency in analysis, a random-effects model was used irrespective of heterogeneity. Heterogeneity was evaluated using the $\mathrm{I}^{2}$ statistic. Heterogeneity less than 40 was considered low, 40 to 60 moderate, and above 60 high. Continuous variables reported as medians were assumed to be equivalent to the mean, and standard deviation (SD) estimation was obtained by dividing the interquartile difference by 1.35 .

\section{Results}

\section{Literature search}

A total of 3,434 articles was identified in the initial search. After removal of duplicates, we filtered 3,217 articles. The first screening excluded 3,116 articles. Full texts of 111 ar- ticles were analyzed. Twenty-eight articles were excluded as review articles and one was not available in English. Ten articles were pediatric studies. Twenty-five were not interventional studies, 18 did not have relevant interventions, five were case reports, three were protocol papers, and 11 were miscellaneous (letter to editors and addendums) (Fig. 1). We included nine randomized control trials and one retrospective cohort with a total of 726 patients. The main characteristics are provided in Table 1 [7-16].

\section{Risk of bias}

The results of the risk of bias are shown in Fig. 2, 3.

\section{Results of quantitative analysis}

The results of quantitative analysis are summarized in Fig. 4 to 6 .
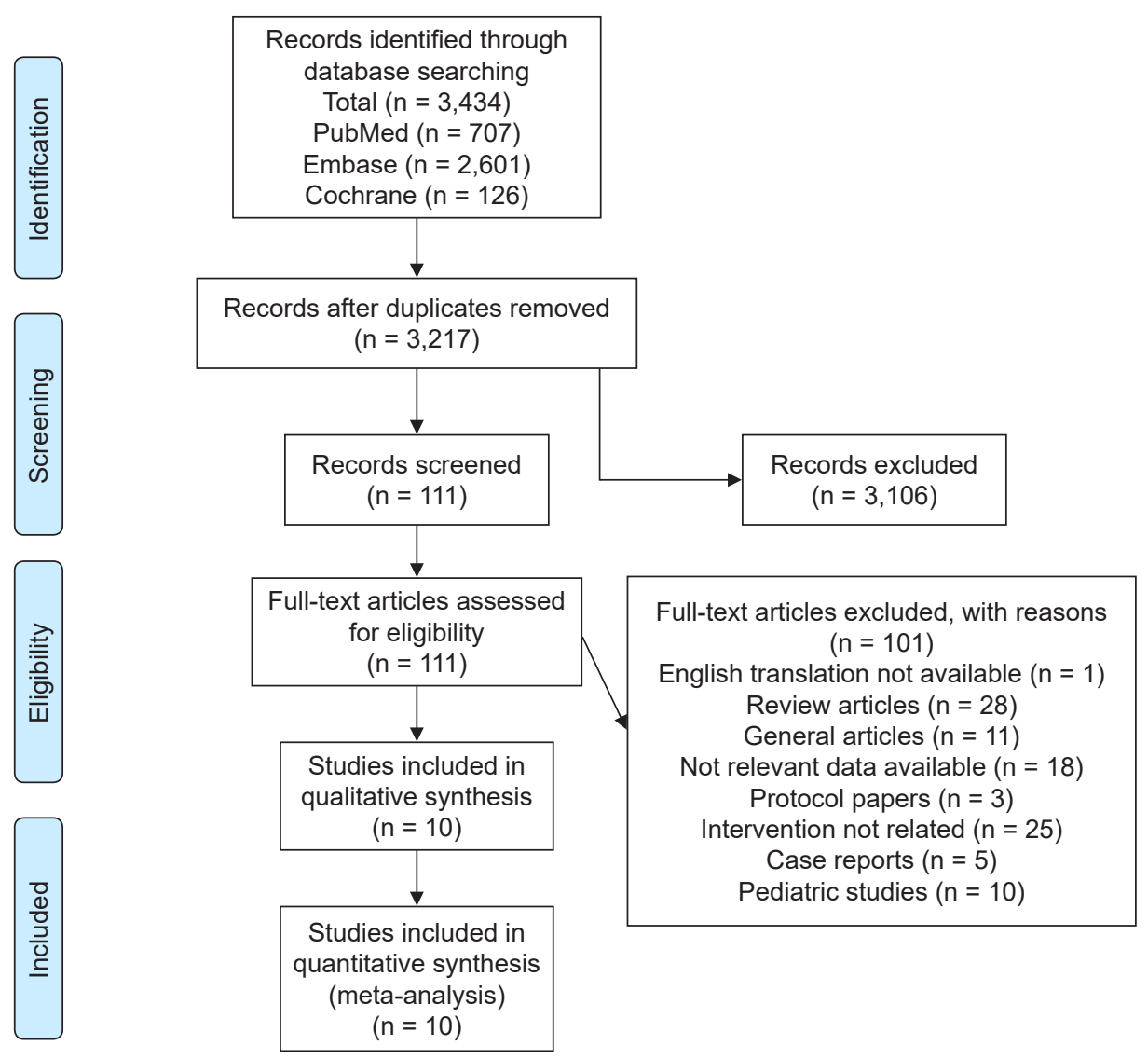

Figure 1. PRISMA (Preferred Reporting Items for Systematic Reviews and Meta-Analyses) chart for the selection of the studies. 


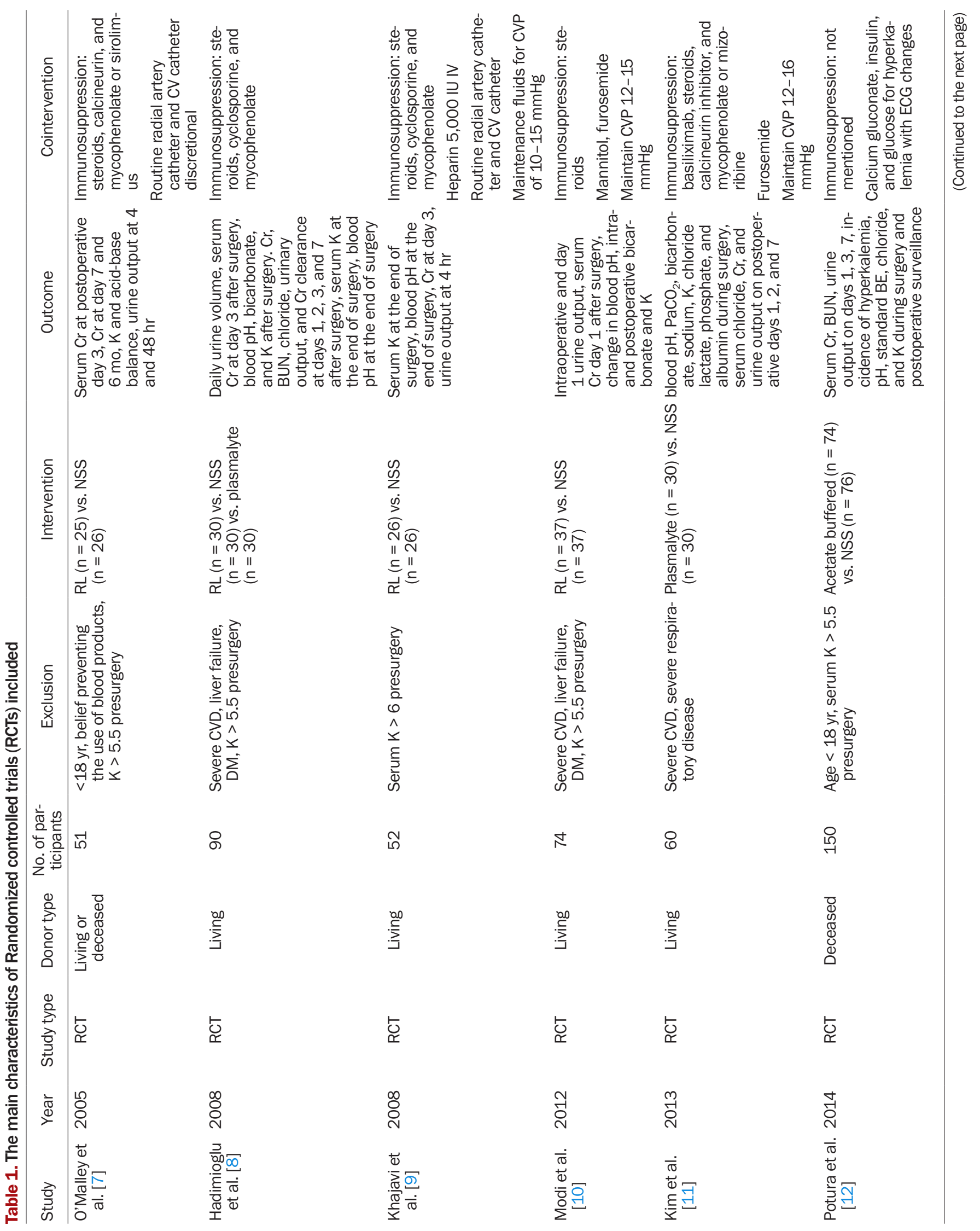




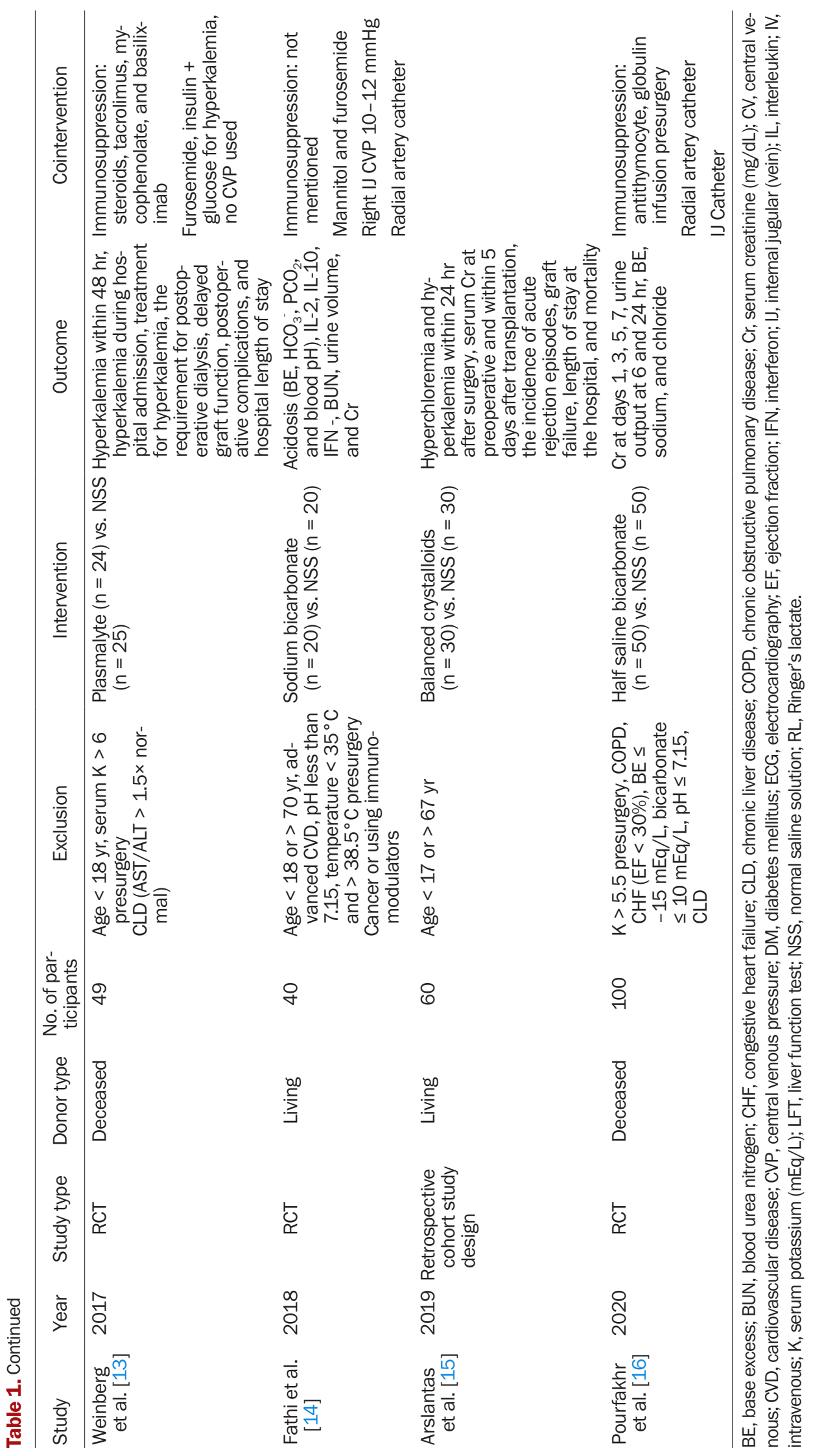




\section{Delayed graft function}

Five studies reported the incidence of delayed graft function. The difference in delayed graft function between the two

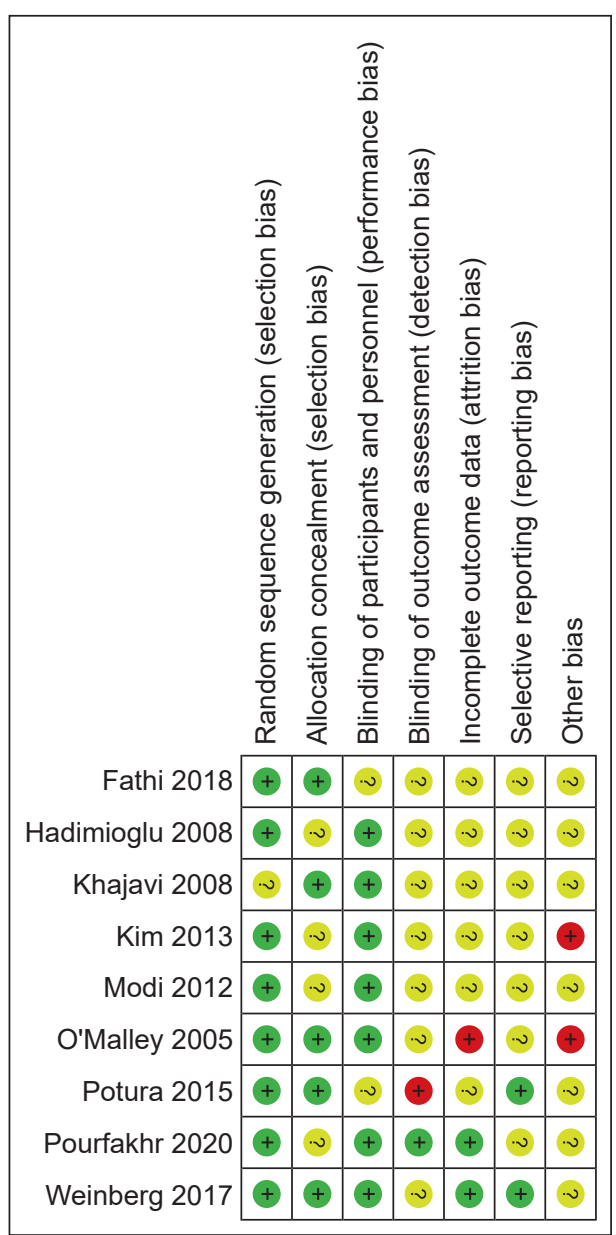

groups was not statistically significant, with an OR of 0.98 (95\% CI, 0.56-1.69; $\mathrm{p}=0.93, \mathrm{I}^{2}=0$ ).

\section{Day 3 creatinine}

Serum creatinine measured at day three after surgery was reported in seven studies and was not statistically significant, with a standardized mean difference of -0.14 (95\% CI, -0.46 to $0.18 ; \mathrm{p}=0.38, \mathrm{I}^{2}=71.525$ ).

\section{Postoperative potassium}

Postoperative potassium was reported in six studies and was significantly lower in the low-chloride group, with a standardized mean difference of -0.38 (95\% CI, -0.66 to -0.11 ; $p$ $=0.007, \mathrm{I}^{2}=48.809$ ).

\section{Postoperative chloride}

Seven studies reported postoperative chloride and showed significantly lower level in the low-chloride group, with a standardized mean difference of -2.41 (95\% CI, -3.34 to -1.48; $\left.\mathrm{p}<0.001, \mathrm{I}^{2}=95.296\right)$.

\section{Postoperative bicarbonate}

Five studies reported postoperative bicarbonate and significantly higher bicarbonate in the low-chloride group, with a standardized mean difference of 0.71 (95\% CI, 0.34-1.08; $\mathrm{p}<$ $\left.0.001, \mathrm{I}^{2}=62.591\right)$.

Figure 2. Results of the risk of biases in the included studies.

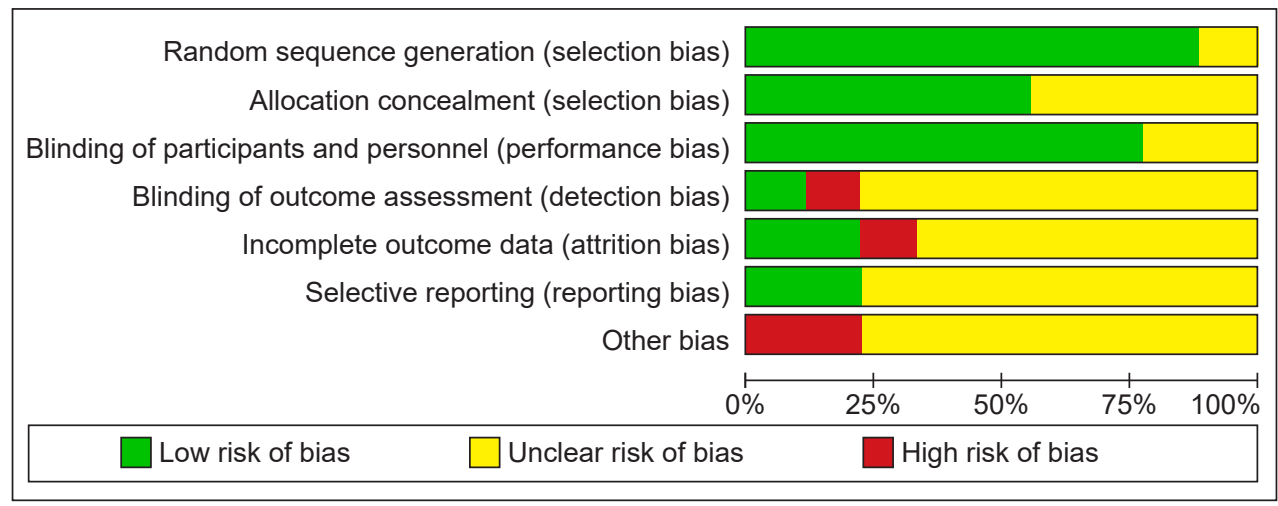

Figure 3. Results of the risk of biases in the included studies. 


\section{(A)}

Study name

$\begin{array}{lccccc} & \begin{array}{c}\text { Odds } \\ \text { ratio }\end{array} & \begin{array}{c}\text { Lower } \\ \text { limit }\end{array} & \begin{array}{c}\text { Upper } \\ \text { limit }\end{array} & \text { Z-value } & \text { p-value } \\ \text { O'Malley (2005) } & 0.50 & 0.042 & 5.889 & -0.55 & 0.58 \\ \text { Hadimioglu (2008) PL } & 0.31 & 0.030 & 3.168 & -0.99 & 0.32 \\ \text { Hadimioglu (2008) RL } & 0.64 & 0.100 & 4.153 & -0.46 & 0.64 \\ \text { Kim (2013) } & 3.22 & 0.316 & 32.889 & 0.99 & 0.32 \\ \text { Potura (2014) } & 1.04 & 0.496 & 2.163 & 0.10 & 0.92 \\ \text { Weinberg (2017) } & 1.14 & 0.338 & 3.859 & 0.22 & 0.83 \\ & 0.98 & 0.564 & 1.685 & -0.09 & 0.93\end{array}$

Odds ratio and $95 \% \mathrm{Cl}$

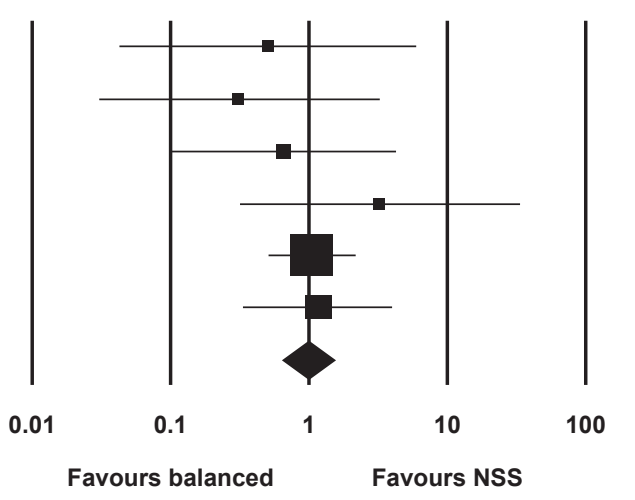

\section{B}

Study name

$\begin{array}{lccccccc} & \begin{array}{c}\text { Standard } \\ \text { difference } \\ \text { in means }\end{array} & \begin{array}{c}\text { Standard } \\ \text { error }\end{array} & \text { Variance } & \begin{array}{c}\text { Lower } \\ \text { limit }\end{array} & \begin{array}{c}\text { Upper } \\ \text { limit }\end{array} & \text { Z-value } & \text { p-value } \\ \text { O'Malley (2005) } & -0.114 & 0.280 & 0.079 & -0.664 & 0.435 & -0.41 & 0.68 \\ \text { Hadimioglu (2008) PL } & -0.102 & 0.258 & 0.067 & -0.608 & 0.405 & -0.39 & 0.69 \\ \text { Hadimioglu (2008) RL } & -0.163 & 0.259 & 0.067 & -0.670 & 0.344 & -0.63 & 0.53 \\ \text { Khajavi (2008) } & 0.184 & 0.278 & 0.077 & -0.361 & 0.729 & 0.66 & 0.51 \\ \text { Potura (2014) } & 0.175 & 0.164 & 0.027 & -0.146 & 0.496 & 1.07 & 0.29 \\ \text { Fathi (2018) } & -0.078 & 0.316 & 0.100 & -0.698 & 0.542 & -0.25 & 0.80 \\ \text { Arslantas (2019) } & 0.078 & 0.258 & 0.067 & -0.428 & 0.585 & 0.30 & 0.76 \\ \text { Pourfakhr (2020) } & -1.065 & 0.214 & 0.046 & -1.484 & -0.646 & -4.98 & <0.001 \\ & -0.142 & 0.163 & 0.027 & -0.462 & 0.177 & -0.87 & 0.38\end{array}$

Standard difference in means and $95 \% \mathrm{Cl}$
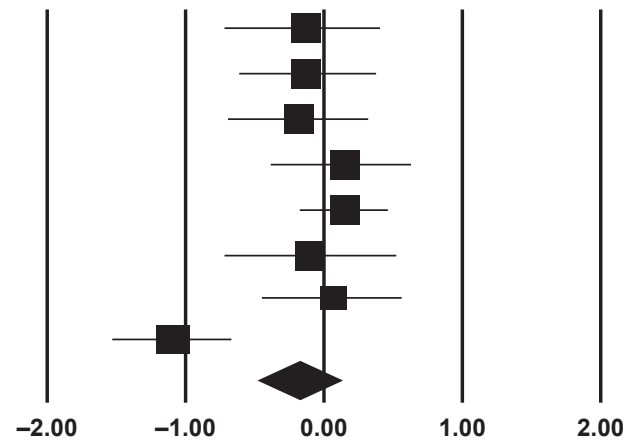

Favours balanced

Figure 4. Results of the risk of biases in the included studies. Quantitative results analysis for delayed graft function and day 3 creatinine. (A) Delayed graft function. (B) Day 3 serum creatinine ( $\mathrm{mg} / \mathrm{dL})$.

$\mathrm{Cl}$, confidence interval; NSS, normal saline solution; RL, Ringer's lactate; PL, plasmalyte.

\section{Day 7 urine output}

The mean difference of urine output at day 7 after surgery was not statistically significant, with a standardized mean difference of -0.08 (95\% CI, -0.29 to $\left.0.12 ; \mathrm{p}=0.43, \mathrm{I}^{2}=0\right)$.

\section{Postoperative blood pH}

Four studies reported postoperative blood $\mathrm{pH}$ and showed a statistically higher blood $\mathrm{pH}$ in the low-chloride group, with a standardized mean difference of 0.84 (95\% CI, 0.23-1.46; p $\left.=0.007, \mathrm{I}^{2}=82.146\right)$.

\section{Postoperative base excess}

Five studies reported postoperative base excess and significant negative base excess in the normal saline group, with a standardized mean difference of 0.99 (95\% CI, 0.42-1.56; $\mathrm{p}=$ $\left.0.001, \mathrm{I}^{2}=87.321\right)$. 
Study name

$\begin{array}{lccccccc} & \begin{array}{c}\text { Standard } \\ \text { difference } \\ \text { in means }\end{array} & \begin{array}{c}\text { Standard } \\ \text { error }\end{array} & \text { Variance } & \begin{array}{c}\text { Lower } \\ \text { limit }\end{array} & \begin{array}{c}\text { Upper } \\ \text { limit }\end{array} & \text { Z-value } & \text { p-value } \\ \text { O'Malley (2005) } & 0.141 & 0.280 & 0.079 & -0.409 & 0.691 & 0.50 & 0.62 \\ \text { Hadimioglu (2008) PL } & -0.300 & 0.260 & 0.067 & -0.809 & 0.209 & -1.16 & 0.25 \\ \text { Hadimioglu (2008) RL } & -0.250 & 0.259 & 0.067 & -0.758 & 0.258 & -0.96 & 0.34 \\ \text { Khajavi (2008) } & -1.131 & 0.299 & 0.089 & -1.716 & -0.545 & -3.79 & <0.001 \\ \text { Modi (2012) } & -0.490 & 0.236 & 0.056 & -0.953 & -0.028 & -2.08 & 0.04 \\ \text { Weinberg (2017) } & -0.596 & 0.292 & 0.085 & -1.168 & -0.023 & -2.04 & 0.04 \\ \text { Arslantas (2019) } & -0.143 & 0.259 & 0.067 & -0.650 & 0.364 & -0.55 & 0.58 \\ & -0.384 & 0.142 & 0.020 & -0.662 & -0.107 & -2.72 & 0.007\end{array}$

\section{B}

Study name

$\begin{array}{lccccccc} & \begin{array}{c}\text { Standard } \\ \text { difference } \\ \text { in means }\end{array} & \begin{array}{c}\text { Standard } \\ \text { error }\end{array} & \text { Variance } & \begin{array}{c}\text { Lower } \\ \text { limit }\end{array} & \begin{array}{c}\text { Upper } \\ \text { limit }\end{array} & \text { Z-value } & \text { p-value } \\ \text { O'Malley (2005) } & 0.851 & 0.293 & 0.086 & 0.278 & 1.424 & 2.91 & 0.00 \\ \text { Hadimioglu (2008) PL } & 1.354 & 0.286 & 0.082 & 0.793 & 1.915 & 4.73 & <0.001 \\ \text { Hadimioglu (2008) RL } & 0.966 & 0.273 & 0.074 & 0.431 & 1.500 & 3.54 & <0.001 \\ \text { Modi (2012) } & 0.651 & 0.239 & 0.057 & 0.184 & 1.119 & 2.73 & 0.006 \\ \text { Weinberg (2017) } & 0.470 & 0.290 & 0.084 & -0.098 & 1.038 & 1.62 & 0.11 \\ \text { Fathi (2018) } & -0.095 & 0.316 & 0.100 & -0.715 & 0.526 & -0.30 & 0.77 \\ & 0.710 & 0.188 & 0.035 & 0.342 & 1.078 & 3.79 & <0.001\end{array}$

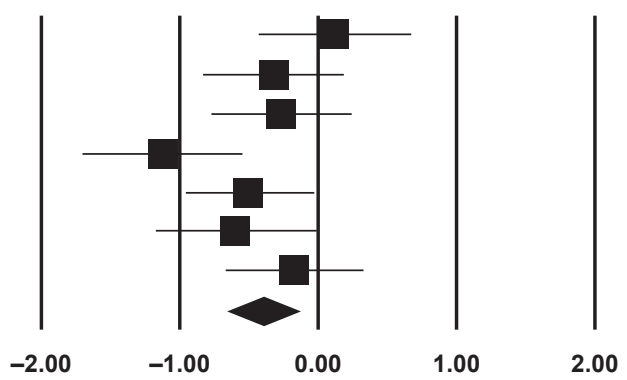

Favours balanced

Favours NSS
Standard difference in means and $95 \% \mathrm{Cl}$

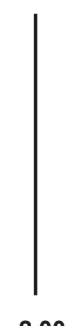

$-1.00$

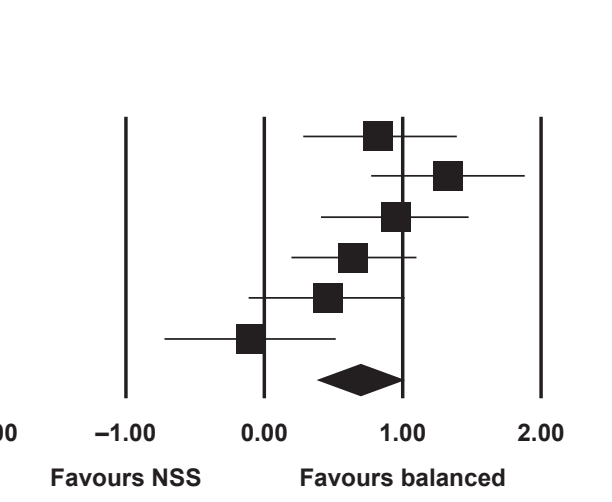

\section{0}

\section{Standard difference in means and $95 \% \mathrm{Cl}$ \\ Statistics for each study}

\section{C}

Study name

$\begin{array}{lccccccc} & \begin{array}{c}\text { Standard } \\ \text { difference } \\ \text { in means }\end{array} & \begin{array}{c}\text { Standard } \\ \text { error }\end{array} & \text { Variance } & \begin{array}{c}\text { Lower } \\ \text { limit }\end{array} & \begin{array}{c}\text { Upper } \\ \text { limit }\end{array} & \text { Z-value } & \text { p-value } \\ \text { O'Malley (2005) } & -1.250 & 0.306 & 0.094 & -1.850 & -0.650 & -4.08 & <0.001 \\ \text { Hadimioglu (2008) PL } & -6.209 & 0.623 & 0.388 & -7.430 & -4.988 & -9.97 & <0.001 \\ \text { Hadimioglu (2008) RL } & -7.104 & 0.698 & 0.487 & -8.472 & -5.736 & -10.18 & <0.001 \\ \text { Modi (2012) } & -1.462 & 0.262 & 0.068 & -1.975 & -0.949 & -5.59 & <0.001 \\ \text { Potura (2014) } & -0.858 & 0.171 & 0.029 & -1.193 & -0.524 & -5.03 & <0.001 \\ \text { Weinberg (2017) } & -1.492 & 0.323 & 0.104 & -2.125 & -0.859 & -4.62 & <0.001 \\ \text { Arslantas (2019) } & -0.600 & 0.264 & 0.070 & -1.117 & -0.083 & -2.27 & 0.02 \\ \text { Pourfakhr (2020) } & -1.795 & 0.237 & 0.056 & -2.259 & -1.331 & -7.58 & <0.001 \\ & -2.406 & 0.474 & 0.225 & -3.336 & -1.477 & -5.07 & <0.001\end{array}$

Statistics for each study
Standard difference in means and $95 \% \mathrm{Cl}$

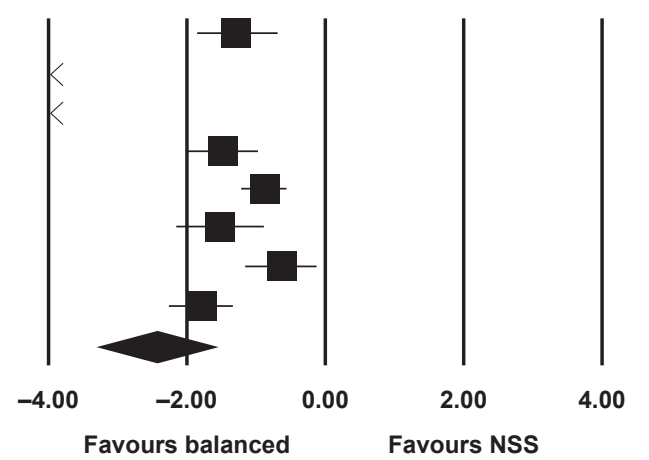

Figure 5. Quantitative results analysis for postoperative potassium, postoperative bicarbonate, and postoperative chloride. (A) Postoperative potassium (mEq/L). (B) Postoperative bicarbonate $(\mathrm{mEq} / \mathrm{L})$. (C) Postoperative chloride $(\mathrm{mEq} / \mathrm{L})$.

$\mathrm{Cl}$, confidence interval; NSS, normal saline solution; RL, Ringer's lactate; PL, plasmalyte. 
A

Study name

$\begin{array}{lccccccc} & \begin{array}{c}\text { Standard } \\ \text { difference } \\ \text { in means }\end{array} & \begin{array}{c}\text { Standard } \\ \text { error }\end{array} & \text { Variance } & \begin{array}{c}\text { Lower } \\ \text { limit }\end{array} & \begin{array}{c}\text { Upper } \\ \text { limit }\end{array} & \text { Z-value } & \text { p-value } \\ \text { Hadimioglu (2008) PL } & -0.266 & 0.259 & 0.067 & -0.774 & 0.242 & -1.03 & 0.31 \\ \text { Hadimioglu (2008) RL } & -0.188 & 0.259 & 0.067 & -0.695 & 0.320 & -0.73 & 0.47 \\ \text { Kim (2013) } & -0.048 & 0.258 & 0.067 & -0.554 & 0.458 & -0.18 & 0.85 \\ \text { Potura (2014) } & -0.057 & 0.163 & 0.027 & -0.377 & 0.263 & -0.35 & 0.73 \\ \text { Fathi (2018) } & 0.194 & 0.317 & 0.100 & -0.427 & 0.816 & 0.61 & 0.54 \\ & -0.083 & 0.104 & 0.011 & -0.287 & 0.121 & -0.80 & 0.43\end{array}$

Standard difference in means and $95 \% \mathrm{Cl}$
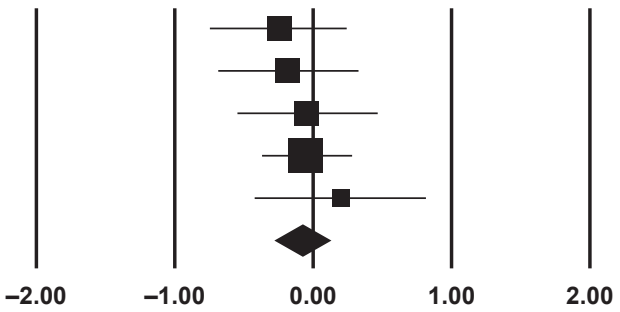

Favours NSS

Favours balanced

\section{B}

Study name

$\begin{array}{lccccccc} & \begin{array}{c}\text { Standard } \\ \text { difference } \\ \text { in means }\end{array} & \begin{array}{c}\text { Standard } \\ \text { error }\end{array} & \text { Variance } & \begin{array}{c}\text { Lower } \\ \text { limit }\end{array} & \begin{array}{c}\text { Upper } \\ \text { limit }\end{array} & \text { Z-value } & \text { p-value } \\ \text { O'Malley (2005) } & 1.286 & 0.308 & 0.095 & 0.683 & 1.889 & 4.18 & <0.001 \\ \text { Hadimioglu (2008) PL } & 1.449 & 0.290 & 0.084 & 0.880 & 2.017 & 4.99 & <0.001 \\ \text { Hadimioglu (2008) RL } & 1.086 & 0.277 & 0.077 & 0.544 & 1.629 & 3.93 & <0.001 \\ \text { Khajavi (2008) } & 0.750 & 0.287 & 0.082 & 0.187 & 1.312 & 2.61 & 0.009 \\ \text { Fathi (2018) } & -0.400 & 0.319 & 0.102 & -1.026 & 0.226 & -1.25 & 0.21 \\ & 0.842 & 0.313 & 0.098 & 0.229 & 1.455 & 2.69 & 0.007\end{array}$

Standard difference in means and $95 \% \mathrm{Cl}$

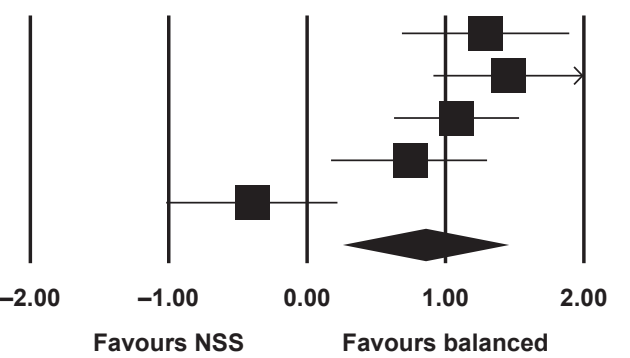

\section{C}

Study name

$\begin{array}{lccccccc} & \begin{array}{c}\text { Standard } \\ \text { difference } \\ \text { in means }\end{array} & \begin{array}{c}\text { Standard } \\ \text { error }\end{array} & \text { Variance } & \begin{array}{c}\text { Lower } \\ \text { limit }\end{array} & \begin{array}{c}\text { Upper } \\ \text { limit }\end{array} & \text { Z-value } & \text { p-value } \\ \text { Hadimioglu (2008) PL } & 1.831 & 0.308 & 0.095 & 1.228 & 2.434 & 5.95 & <0.001 \\ \text { Hadimioglu (2008) RL } & 1.975 & 0.315 & 0.099 & 1.358 & 2.592 & 6.27 & <0.001 \\ \text { Kim (2013) } & 0.980 & 0.273 & 0.075 & 0.444 & 1.515 & 3.59 & <0.001 \\ \text { Potura (2014) } & 0.773 & 0.169 & 0.029 & 0.441 & 1.105 & 4.57 & <0.001 \\ \text { Fathi (2018) } & -0.459 & 0.320 & 0.103 & -1.087 & 0.169 & -1.43 & 0.15 \\ \text { Pourfakhr (2020) } & 0.852 & 0.209 & 0.044 & 0.443 & 1.262 & 4.08 & <0.001 \\ & 0.987 & 0.290 & 0.084 & 0.418 & 1.555 & 3.40 & 0.001\end{array}$

Standard difference in means and $95 \% \mathrm{Cl}$

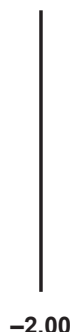

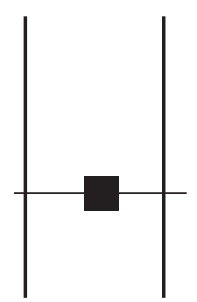

$-1.00$

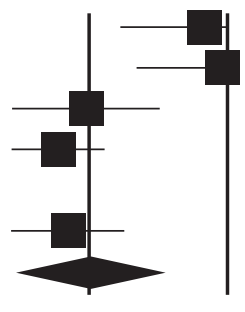

$1.00 \quad 2.00$
Favours NSS

Figure 6. Quantitative results analysis for day 7 urine output, postoperative blood pH, and postoperative base excess. (A) Day 7 urine output (L). (B) Postoperative blood pH. (C) Postoperative base excess.

$\mathrm{Cl}$, confidence interval; NSS, normal saline solution; RL, Ringer's lactate; PL, plasmalyte. 


\section{Subgroup analysis}

We performed subgroup analysis for delayed graft function, day 3 creatinine, and postoperative potassium level in studies that only included living donors.

The OR for delayed graft function remained not statistically significant $(0.83 ; 95 \% \mathrm{CI}, 0.24-2.90 ; \mathrm{p}=0.77)$. Similarly, the OR of day three creatinine was not statistically significant with a random-effects model $(-0.21 ; 95 \% \mathrm{CI},-0.62$ to 0.20$)$. The OR for postoperative potassium level remained significantly lower in the low-chloride group $(-0.44 ; 95 \% \mathrm{CI},-0.76$ to $-0.13 ; \mathrm{p}=0.006$ ).

\section{Summary of results}

Low-chloride solutions were associated with lower chloride and potassium levels, less negative base excess, and higher blood $\mathrm{pH}$ postoperatively without significant difference in postoperative delayed graft function, day 3 creatinine, or urine output at day 7.

\section{Discussion}

Intraoperative fluid management during kidney transplants has been a topic of discussion for the past decade. Transplant physicians have extensively debated the fluid of choice based on composition, like chloride or potassium concentration, blood $\mathrm{pH}$, and tonicity. Since low-chloride solutions (like lactated Ringer's) have a higher concentration of potassium that can theoretically cause hyperkalemia, NSS is considered the fluid of choice during renal transplant [7]. Nevertheless, due to its high chloride concentration, NSS can cause hyperchloremic metabolic acidosis, leading to compensatory hyperkalemia in patients during the initial posttransplant period $[8,17]$. Several trials have exhibited hyperchloremia with adverse outcomes in kidney transplant patients [18-20].

It is postulated that supraphysiologic level of chloride releases thromboxane and augmented responses to renal vasoconstrictors [21]. Furthermore, increased chloride delivery to the macula densa leads to tubuloglomerular feedback resulting in afferent arteriolar vasoconstriction, mesangial contractions, and decreased glomerular filtration rate [22].

The debate about ideal fluid during kidney transplants continues. Colloids usually are not used because they are associated with several adverse effects, including renal failure $[23,24]$. Our study looked for factors like delayed graft function or clinically significant hyperkalemia in patients who received NSS versus low-chloride solutions. The last study performed on choice of fluids during renal transplant is the Cochrane review published in 2016, with 6 RCTs and 477 participants [6]. A previous meta-analysis included four RCTs with a total of 267 participants $(n=267)$ [25]. Since 2016, there have been three more RCTs, necessitating inclusion of these studies to increase population size and unmask any missed differences. Our study included nine RCTs and one retrospective cohort study with a total of 276 total participants $(\mathrm{n}=276)$.

Our study shows that low-chloride solutions are better than NSS when transfused during renal transplant. We noticed increased risk of hyperchloremia and base deficit (both of which lead to metabolic acidosis) with NSS. The high chloride leads to loss of bicarbonate and ultimately acidosis. Potassium acts as a buffer to acidosis, resulting in hyperkalemia.

In terms of acid-base balance, the blood $\mathrm{pH}$ was significantly lower in the NSS group (OR, 0.84; 95\% CI, 0.23-1.46; p $\left.=0.007, \mathrm{I}^{2}=82.146\right)$. The low-chloride solution group showed increased postoperative serum bicarbonate and blood $\mathrm{pH}$ levels. A new significant finding compared to previous meta-analyses like Trujillo-Zea et al. [25] and the Cochrane review [6] is postoperative hyperkalemia (mean difference, $-0.38 ; 95 \%$ CI, -0.66 to $-0.11 ; \mathrm{p}=0.007, \mathrm{I}^{2}=48.809$ ) in the NSS group when analyzed under a random-effects model. The postoperative potassium was higher in the NSS group in all studies except for O'Malley et al. [7], likely because the baseline potassium level was higher in the low-chloride group ( $4.5 \pm 0.5$ compared to $4.2 \pm 0.7$ in the NSS group).

For the patients receiving treatment for acidosis after transplantation, the trend seemed inclined toward NSS in all the studies except Weinberg et al. Overall, the difference was not statistically significant likely due to the small number of patients.

We observed high heterogeneity in postoperative blood $\mathrm{pH}$, chloride, bicarbonate, and base excess. The heterogeneity can be attributed to concurrent interventions such as in Fathi et al. [14] where all the patients were given $50 \mathrm{~mL} /$ $\mathrm{kg}$ of normal saline. For example, when Fathi et al. [14] was excluded from the analysis for $\mathrm{pH}$, the standardized mean difference increased to 1.14 (95\% CI, 0.85-1.42), reducing I $\mathrm{I}^{2}$ 
to 7.524. Similarly, the bicarbonate standardized mean difference increased to 0.85 (95\% CI, 0.56-1.14), reducing $\mathrm{I}^{2}$ to 29.683. Additionally, a variable amount of fluid administration in the pre- and postoperative periods also added to the study heterogeneity.

There was no significant difference in delayed graft function, creatinine at day three, or urine output on postoperative day 7 , and heterogeneity was small. This finding is important because, in the past, use of low-chloride solutions like Ringer's lactate has been discouraged due to risk of postoperative hyperkalemia and renal injury. In this study, there was no difference in postoperative urine output, blood urea nitrogen, or creatinine levels with fluid use, indicating that low-chloride solutions are as safe as if not better than NSS during kidney transplant surgery.

The study's major strengths include a larger patient population analyzed than earlier reviews and comprehensive analysis of multiple parameters. This study revealed a significant finding in contrast to previous meta-analyses like Trujillo-Zea et al. [25] and the Cochrane review [6]. Postoperative hyperkalemia (standardized mean difference, -0.38 ; $95 \% \mathrm{CI},-0.66$ to $-0.11 ; \mathrm{p}=0.007, \mathrm{I}^{2}=48.809$ ) was seen in the NSS group when analyzed under a random-effects model.

Being a meta-analysis, this study remains a retrospective chart review and creates the possibility for biases. Smaller numbers of trials and people enrolled lead to publication bias. The difference in composition of low-chloride solutions creates potential bias. Although there is a difference in chloride concentration in these solutions among studies, they have less chloride than NSS. We excluded colloid fluids produced in normal saline as they have the same chloride content as NSS (e.g., hydroxyethyl starches in normal saline) to minimize the bias. However, we aimed to prove that using these fluids with lower-chloride solution than NSS would reduce the risk of hyperchloremia to result in less hyperkalemia and acidosis, as seen in the results. Another significant limitation is the different follow-up times at which the readings were obtained. We attempted to tackle this by choosing readings closest to each other in timing to minimize the bias in the results.

Overall, we made our best effort to search for all published studies, randomize them, and complete data extraction and analysis. These trials are based on intraoperative use of fluids. Transplant patients undergo a large amount of intravenous fluid infusion at 48 to 72 hours after surgery. Postoper- ative values for creatinine, potassium, bicarbonate, and $\mathrm{pH}$ vary with type of fluid used during this postoperative period, and further studies are needed to take this into account.

In conclusion, low-chloride solutions are a safe alternative to NSSs in renal transplant patients, and their use is associated with lower potassium, chloride, and higher $\mathrm{pH}$ postoperatively. They could be the fluids of choice in patients with high risk of hyperkalemia and acidosis during surgery.

\section{Conflicts of interest}

All authors have no conflicts of interest to declare.

\section{Authors' contributions}

Investigation: SS, Abdullah Jahangir, MRKN, FSS, MYA, Ahmad Jahangir

Data curation: Abdullah Jahangir, EJE

Writing-original draft: SS, Abdullah Jahangir, MRKN, FSS, MYA, Ahmad Jahangir

Writing-review \& editing: Abdullah Jahangir, EJE

All authors read and approved the final manuscript.

\section{ORCID}

Abdullah Jahangir, https://orcid.org/0000-0002-7758-3318

Syeda Sahra, https://orcid.org/0000-0003-0119-3329

Muhammad Rafay Khan Niazi, https://orcid.org/0000-00024615-3147

Fasih Sami Siddiqui, https://orcid.org/0000-0002-5676-9172 Muhammad Yasir Anwar, https://orcid.org/0000-0001-9471735X

Ahmad Jahangir, https://orcid.org/0000-0002-7758-3318

Elie J El-Charabaty, https://orcid.org/0000-0003-4989-6023

\section{References}

1. O’Malley CM, Frumento RJ, Hardy MA, et al. A randomized, double-blind comparison of lactated Ringer's solution and $0.9 \%$ $\mathrm{NaCl}$ during renal transplantation. Anesth Analg 2005;100:15181524.

2. Belani KG, Palahniuk RJ. Kidney transplantation. Int Anesthesiol Clin 1991;29:17-39.

3. Murphy BA. Anesthesiologist's manual of surgical procedures, 3rd ed. Anesth Analg 2004;99:314. 
4. Wilkes NJ, Woolf R, Mutch M, et al. The effects of balanced versus saline-based hetastarch and crystalloid solutions on acid-base and electrolyte status and gastric mucosal perfusion in elderly surgical patients. Anesth Analg 2001;93:811- 816.

5. Yarlagadda SG, Coca SG, Garg AX, et al. Marked variation in the definition and diagnosis of delayed graft function: a systematic review. Nephrol Dial Transplant 2008;23:2995-3003.

6. Wan S, Roberts MA, Mount P. Normal saline versus lower-chloride solutions for kidney transplantation. Cochrane Database Syst Rev 2016;(8):CD010741.

7. O'Malley CM, Frumento RJ, Bennett-Guerrero E. Intravenous fluid therapy in renal transplant recipients: results of a US survey. Transplant Proc 2002;34:3142-3145.

8. Hadimioglu N, Saadawy I, Saglam T, Ertug Z, Dinckan A. The effect of different crystalloid solutions on acid-base balance and early kidney function after kidney transplantation. Anesth Analg. 2008;107:264-269.

9. Khajavi MR, Etezadi F, Moharari RS, et al. Effects of normal saline vs. lactated ringer \'s during renal transplantation. Ren Fail 2008;30:535-539.

10. Modi MP, Vora KS, Parikh GP, Shah VR. A comparative study of impact of infusion of Ringer $\backslash$ 's lactate solution versus normal saline on acid-base balance and serum electrolytes during live related renal transplantation. Saudi J Kidney Dis Transpl 2012;23:135-137.

11. Kim SY, Huh KH, Lee JR, Kim SH, Jeong SH, Choi YS. Comparison of the effects of normal saline versus plasmalyte on acid-base balance during living donor kidney transplantation using the Stewart and base excess methods. Transplant Proc. 2013;45:2191-2196.

12. Potura E, Lindner G, Biesenbach P, et al. An acetate-buffered balanced crystalloid versus $0.9 \%$ saline in patients with endstage renal disease undergoing cadaveric renal transplantation: a prospective randomized controlled trial. Anesth Analg 2015;120:123-129.

13. Weinberg L, Harris L, Bellomo R, et al. Effects of intraoperative and early postoperative normal saline or Plasma-Lyte $148^{\circledR}$ on hyperkalaemia in deceased donor renal transplantation: a double-blind randomized trial. Br J Anaesth 2017;119:606-615.

14. Fathi M, Massoudi N, Alirezaei A, Bakhtiyari M. Treatment of metabolic acidosis in altering inflammatory biomarkers in renal transplant recipients; a randomized clinical trial. Iran Red Crescent Med J 2018;20:e68102.

15. Arslantas R, Dogu Z, Cevik BE. Normal saline versus balanced crystalloid solutions for kidney transplantation. Transplant Proc 2019;51:2262-2264.

16. Pourfakhr P, Shafiei M, Etezadi F, Khajavi MR, Moharari RS. Half saline-bicarbonate solution as intraoperative fluid replacement therapy leads to less acidosis and better early renal function during deceased-donor transplant. Exp Clin Transplant 2020;18:34-38.

17. Prough DS, Bidani A. Hyperchloremic metabolic acidosis is a predictable consequence of intraoperative infusion of $0.9 \%$ saline. Anesthesiology 1999;90:1247-1249.

18. Wilcox CS. Regulation of renal blood flow by plasma chloride. $J$ Clin Invest 1983;71:726-735.

19. Ricaurte L, Vargas J, Lozano E, Díaz L; Organ Transplant Group. Anesthesia and kidney transplantation. Transplant Proc 2013;45:13861391.

20. Etezadi F, Pourfakhr P, Mojtahedzade M, et al. Effects of tight versus non tight control of metabolic acidosis on early renal function after kidney transplantation. Daru 2012;20:36.

21. Bullivant EM, Wilcox CS, Welch WJ. Intrarenal vasoconstriction during hyperchloremia: role of thromboxane. Am J Physiol 1989; 256(1 Pt 2):F152-F157.

22. Hansen PB, Friis UG, Uhrenholt TR, Briggs J, Schnermann J. Intracellular signalling pathways in the vasoconstrictor response of mouse afferent arterioles to adenosine. Acta Physiol (Oxf) 2007;191:89-97.

23. Willms CD, Dawidson IJ, Dickerman R, Drake D, Sandor ZF, Trevino $\mathrm{G}$. Intraoperative blood volume expansion induces primary function after renal transplantation: a study of 96 paired cadaver kidneys. Transplant Proc 1991;23(1 Pt 2):1338-1339.

24. Dawidson IJ, Ar'Rajab A. Perioperative fluid and drug therapy during cadaver kidney transplantation. Clin Transpl 1992;267284.

25. Trujillo-Zea JA, Aristizábal-Henao N, Fonseca-Ruiz N. Lactated Ringer's vs. normal saline solution for renal transplantation: systematic review and meta-analysis. Rev Colomb de Anestesiol 2015;43:194-203. 